\title{
Delayed Germination of Cheatgrass Seed
}

\section{A. C. HULL, JR., AND W. THERON HANSEN, JR.}

Highlight: Cheatgrass seeds germinate readily and usually near 100\% shortly after collection. Generally, practically all seeds that fall to the ground germinate and plants emerge with favorable conditions in the fall, during the winter, or in early spring. In this study, an average of 692 cheatgrass plants $/ \mathrm{ft}^{2}$ emerged the first year. In the same soil samples, 273 seeds $/ \mathrm{ft}^{2}$ did not germinate but produced plants when these seeds were brought into favorable conditions in the greenhouse. When these ungerminated seeds remain in the soil-litter mass in the field, they germinate and emerge more slowly than seeds brought into the greenhouse. Seeds that remain in seedheads over winter germinate slowly but with a high percent when placed in a germinator. Nitrogen at $80,160,320$, and 640 lb/acre caused the number of plants that emerged in the field to decrease slightly as the rate of fertilizer increased.

Cheatgrass (Bromus tectorum L.), an aggressive introduced winter annual, is well adapted to large areas of rangeland, especially in the western

Authors are range scientist and range technician, Agricultural Research Service, U.S. Department of Agriculture, Logan, Utah.

This paper is a joint contribution from Agr. Res. Serv., U.S. Dep. Agr. and Utah Agricultural Experiment Station, Logan, Utah. (Utah Agr. Exp. Sta. Journal Paper No. 1775.)

Manuscript received September 15, 1973.
United States. Though cheatgrass produces large volumes of feed, it has many undesirable characteristics, and rangeland values would be improved if cheatgrass could be replaced by more desirable forage species. Replacement is difficult, however, because cheatgrass produces abundant seed and seedlings that compete with and often prevent successful establishment of seedlings of perennial grasses (Evans, 1961; Hull, 1963; Harris, 1967; Klomp and Hull, 1972). To successfully revegetate cheatgrass areas with more desirable species, we must eliminate cheatgrass seeds and plants.

Cheatgrass seeds in dry storage remain viable for several years. Seeds stored in a laboratory up to 11.5 years germinated from 95 to $100 \%$ (Hulbert, 1955). Seeds stored in unheated sheds up to 12 years germinated 98 to $100 \%$. Seeds stored from 28 to 40 years did not germinate (Hull, 1973). ${ }^{1}$

Many workers have reported that cheatgrass seeds germinate in the fall, winter, or early spring and that practically all of the seeds germinate as soon as conditions are favorable (Warg, 1938; Chepil, 1946; Stewart and Hull, 1949; Hulbert, 1955; Klemmedson and Smith, 1964). Klemmedson and Smith (1964) observed regrowth from new tillers in late spring, after plants

\footnotetext{
${ }^{1}$ Also, unpublished file data.
} 
had matured and dried considerably. They thought that this might explain the "second crop" from seed that some persons have observed.

Warg (1938) reported that cheatgrass seeds subjected to high moisture and freezing temperatures during the winter germinated only 3\% in the spring. This contrasts with $99 \%$ germination of seed in dry storage. He concluded that there is little field germination of cheatgrass in the spring.

Young et al. (1969) found that freshly harvested cheatgrass seeds germinate $95 \%$ within 2 weeks. However, ungerminated seeds that spent one winter in the soil exposed to freezing and thawing were collected in May 1965 and when placed in favorable conditions, germinated continuously for one 12-week period in each of 3 years; 1965, 1966, and 1967. Some physiologic process in the seed converts it from simultaneous to continuous or intermittent delayed germination, and thus large numbers of viable seeds are carried from one year to the next in the litter and soil.

In the late winter of 1964, we observed a light density of cheatgrass seedlings on an area where cheatgrass had been plowed after emergence the previous fall. Also, in the fall of 1965 we found many cheatgrass seeds in the soil after good fall emergence. These seeds exhibited "continuous" or delayed germination under greenhouse conditions without having been exposed over winter.

The purpose of this study was to determine the number of germinable cheatgrass seeds in the soil after supposedly complete emergence.

\section{Location and Procedures}

We collected soil containing cheatgrass and cheatgrass seeds at three areas: Wendell, Ida., and Promontory and Logan, Utah. The original vegetation on all three areas was sagebrushgrass. The sagebrush (mainly Artemisia tridentata) had been burned and the perennial grasses (mainly Agropyron spicatum and $A$. riparium) either plowed or grazed to extinction, leaving good stands of cheatgrass. Wendell is at 3,500 ft elevation, annual precipitation averages 8.5 inches, and the soil is Portneuf sandy loam. Promontory is at $4,400 \mathrm{ft}$ elevation, annual precipitation averages 15 inches, and the soil is a Kearns silt loam. Logan is at $4,800 \mathrm{ft}$ elevation, annual precipitation is 17

Table 1. Field and greenhouse emergence of cheatgrass plants $/ \mathrm{ft}^{2}$ at three locations 1965 to 1973.

\begin{tabular}{|c|c|c|c|c|c|c|c|}
\hline \multirow{3}{*}{$\begin{array}{l}\text { Location and } \\
\text { place of } \\
\text { emergence }^{a}\end{array}$} & \multicolumn{7}{|c|}{ Season and year collected } \\
\hline & \multirow{2}{*}{$\begin{array}{c}1965 \\
\text { Fall }\end{array}$} & \multirow{2}{*}{$\begin{array}{c}1966 \\
\text { Spring }\end{array}$} & \multicolumn{2}{|c|}{1971} & \multicolumn{2}{|c|}{1972} & \multirow{2}{*}{$\begin{array}{c}1973 \\
\text { Spring }\end{array}$} \\
\hline & & & Spring & Fall & Spring & Fall & \\
\hline \multicolumn{8}{|l|}{ Wendell } \\
\hline Field & - & 822 & 1,329 & 845 & 451 & 1,118 & 883 \\
\hline Greenhouse & - & 154 & 667 & $257^{\mathrm{b}}$ & 202 & 179 & 80 \\
\hline Total & - & 976 & 1,996 & $1,102^{\mathrm{c}}$ & 653 & 1,297 & 963 \\
\hline $\mathrm{DE}^{\mathrm{a}}$ & - & 159 & 203 & 52 & 223 & 208 & 157 \\
\hline \multicolumn{8}{|l|}{ Promontory } \\
\hline Field & 419 & 590 & 1,223 & 912 & 447 & 355 & 183 \\
\hline Greenhouse & $704^{c}$ & 274 & 206 & $199^{d}$ & 165 & 86 & 59 \\
\hline Total & 1,123 & 864 & 1,429 & $1,111^{\mathrm{d}}$ & 612 & 441 & 242 \\
\hline $\mathrm{DE}$ & $20^{c}$ & 205 & 142 & $96^{d}$ & 174 & 204 & 142 \\
\hline \multicolumn{8}{|l|}{ Logan } \\
\hline Field & 447 & 726 & 972 & 759 & 441 & 949 & $194^{\mathrm{f}}$ \\
\hline Greenhouse & $505^{c}$ & 417 & 245 & $231^{\mathrm{e}}$ & 113 & 346 & 20 \\
\hline Total & 952 & 1,143 & 1,217 & $990^{\mathrm{e}}$ & 554 & 1,295 & 214 \\
\hline $\mathrm{DE}$ & $20^{\mathrm{c}}$ & 210 & 183 & $97^{\mathrm{e}}$ & 201 & 214 & 139 \\
\hline \multicolumn{8}{|l|}{ Average } \\
\hline Field & 448 & 713 & 1,174 & 839 & 446 & 807 & 420 \\
\hline Greenhouse & 605 & 282 & 373 & 229 & 160 & 204 & 53 \\
\hline Total & 1,053 & 995 & 1,547 & 1,068 & 606 & 1,011 & 473 \\
\hline $\mathrm{DE}$ & $20^{\mathrm{c}}$ & 191 & 176 & 82 & 199 & 209 & 146 \\
\hline
\end{tabular}

${ }_{\mathrm{DE}}^{\mathrm{a}}=$ days from first to last greenhouse emergence.

${ }^{b}$ Germinated 52 days, stored 256 days, then germinated for 73 days. No emergence after storage.

c Samples discarded because emergence was slow.

$\mathrm{d}_{\text {Germinated }} 80$ days, stored 256 days, then germinated for 73 days. Emergence during these 73 days accounts for 118 plants and 16 days of germination included here.

${ }^{e}$ Germinated 86 days, stored 256 days, then germinated for 73 days. Emergence during these 73 days accounts for 59 plants and 11 days of germination included here.

$f$ Winterkill, mainly snow mold.

inches, and the soil is deep Timpanogos silt loam. At all locations, precipitation was near normal during the years of the study.

We collected 10 samples of soil including emerged cheatgrass plants and surface litter at seven dates as follows: fall, 1965; spring, 1966; spring and fall, 1971 and 1972; and spring, 1973. Samples were either 4 by 4 or 6 by 6 inches and 0.8 inch deep. For uniformity, all samples were converted to plants $/ \mathrm{ft}^{2}$. Fall samples were taken so that fall emergence would be complete; spring samples were taken when seedlings stopped emerging. The emerged cheatgrass plants were counted and removed. One inch of soil was placed in a pot that had been partly filled with a greenhouse soil mixture. Pots were placed in the greenhouse and watered. As seedlings emerged, we counted and removed the seed and its plant. Greenhouse temperatures during the day usually ranged from $46^{\circ}$ to $92^{\circ} \mathrm{F}$ with a mean of $76^{\circ} \mathrm{F}$ and during the night from $47^{\circ}$ to $82^{\circ} \mathrm{F}$, with a mean of $64^{\circ} \mathrm{F}$.

After cheatgrass emergence in the fall of 1971 we selected six 4- by 4-inch samples on each area, counted and removed the cheatgrass plants, and covered each sample with plastic and fine screen to protect it from outside seeds. As cheatgrass plants emerged in these samples during 1972 and 1973, they were counted and removed.

In the spring of 1966, 1972, and 1973, we collected cheatgrass seeds from panicles that had retained seeds over winter. Two lots of 100 seeds from each area were germinated soon after collection. We also collected seeds at maturity during the previous summer, stored them in the laboratory, and germinated them as a check on seeds that remained over winter in the panicle.

In the fall of 1971, we applied nitrogen at $0,80,160,320$, and 640 $\mathrm{lb} / \mathrm{acre}$ to 10 - by 10 -ft plots on all areas to determine its effect upon seed germination.

\section{Results and Discussion}

Moisture was adequate in all seasons, and temperatures were suitable for good field emergence. However, there were many ungerminated cheatgrass seeds in the soil after field emergence was apparently complete (Table 1). Germination varied widely among years and between seasons. In the greenhouse, the greatest number of seeds emerged from the fall of 1965 samples, whereas the fewest emerged from the spring of 1973 samples. The 
amount of delayed emergence did not seem to be related to precipitation.

Averaging all years, 692 cheatgrass plants $/ \mathrm{ft}^{2}$ emerged in the field and 273 plants $/ \mathrm{ft}^{2}$ that failed to emerge in the field, emerged later from the same soil samples in the greenhouse. If the 273 seeds $/ \mathrm{ft}^{2}$ in the soil after apparent complete emergence of cheatgrass would germinate at once, there would be enough for a full stand of cheatgrass that could prevent establishment of seeded. species. However, delayed germination of seeds in this amount has been rarely observed, and then only when the spring season was long and exceptionally wet. Severe competition of species seeded in cheatgrass areas can normally be avoided by killing all cheatgrass plants and preventing seed formation the year of seeding.

Seedlings emerged in the field more rapidly than in the greenhouse. When soil moisture and temperatures are favorable, field emergence may be completed within a few days. The span of plant emergence in the greenhouse varied from 52 to 223 days, with an average of 167 days. The 20-day emergence in 1965 is excluded because the samples were discarded when the rate of emergence decreased.

Germination in the greenhouse may be interrupted by drying and seeds may then continue germination. Samples collected in the fall of 1971 germinated in the greenhouse for 52 to 86 days, were stored in an unheated shed for 256 days, and then germinated in the greenhouse for another 73 days. During the second germination period in the greenhouse, plants emerged from the Promontory and Logan samples (Table 1).
Field samples protected by plastic had 787 cheatgrass plants $\mathrm{ft}^{2}$ when established in the fall of 1971. These plants were removed and an additional 197 plants $/ \mathrm{ft}^{2}$ emerged on these plots. Thirty-one plants emerged in the spring of 1972, 161 that fall, and five during the spring of 1973. Delayed germination in the field was $20 \%$ as compared with $21 \%$ when seeds and soil were brought into the greenhouse.

Cheatgrass seeds collected at maturity averaged $99 \%$ germination. Seeds that remained over winter in the panicle germinated from 74 to $100 \%$, with an average of $96 \%$. Seeds kept in dry storage required from 2 to 7 days for emergence, those that remained over winter in the panicle required 5 to 52 days, and those from the soil and litter required from 52 to 223 days.

The first spring after fertilization, the number of plants that emerged in the field decreased as the rate of fertilizer increased. Rate of fertilizer did not affect the number of plants that emerged in the greenhouse. The fall after fertilizer application, the number of plants that emerged in the field increased slightly, and the number that emerged in the greenhouse decreased as the rate of fertilizer increased.

\section{Conclusions}

After fall and spring emergence of cheatgrass is complete, usually enough ungerminated seed is left in the soil to produce a full stand of cheatgrass that could compete with seeded species if all the seed should germinate at the same time. However, complete germination at one season is rare. Therefore, severe competition of species seeded in cheatgrass areas can normally be avoided by killing all cheatgrass plants and preventing seed production the year of seeding. Fertilization does not appear to be practical as a method of manipulating cheatgrass stands.

\section{Literature Cited}

Chepil, W. A. 1946. Germination of weed seeds. 1. Longevity, periodicity of germination, and vitality of seeds in cultivated soil. Sci. Agr. 26:307-346.

Evans, R. A. 1961. Effects of different densities of downy brome (Bromus tectorum) on growth and survival of crested wheatgrass (Agropyron desertorum) in the greenhouse. Weeds 9:216-223.

Harris, G. A. 1967. Some competitive relationships between Agropyron spicatum and Bromus tectorum. Ecol. Monogr. 37:89-111.

Hulbert, L. C. 1955. Ecological studies of Bromus tectorum and other annual bromegrasses. Ecol. Monogr. 25:181-213.

Hull, A. C., Jr. 1963. Competition and water requirements of cheatgrass and wheatgrass in the greenhouse. J. Range Manage. 16:199-204.

Hull, A. C., Jr. 1973. Seed germination after long periods of uncontrolled storage. $\mathbf{J}$. Range Manage. 26:198-200.

Klemmedson, J. O., and J. G. Smith. 1964. Cheatgrass (Bromus tectorum L.). Bot. Rev. 30:226-262.

Klomp, G. J., and A. C. Hull, Jr. 1972. Methods for seeding three perennial wheatgrasses on cheatgrass range in Southern Idaho. J. Range Manage. 25:266-268.

Stewart, George, and A. C. Hull, Jr. 1949. Cheatgrass (Bromus tectorum L.)-An ecological intruder in Southern Idaho. Ecology 30:58-74.

Warg, S. A. 1938. Life history and economic studies on Bromus tectorum. MS thesis. Univ. of Montana, Missoula. 38 p.

Young, J. A., R. A. Evans, and R. E. Eckert, Jr. 1969. Population dynamics of downy brome. Weed Sci. 17:20-26.

\section{RANGELAND ENTOMOLOGY}

by George B. Hewitt, Ellis W. Huddleston, Robert J. Lavigne, Darrell N. Ueckert, and J. Gordon Watts

SRM Range Science Series No. 2

Soft cover; well illustrated; extensive bibliography

\$2.25 per copy, postpaid.* Order today from-

Society for Range Management, 2120 South Birch St., Denver, Colorado 80222
"The quest for knowledge, concern for the preservation of a wholesome environment, and the ever-growing demand for greater production from the vast expanse of rangeland have merged to focus attention on the importance of insects in range ecosystems. These small animals are omnipresent on rangeland and play a role that is most often subtle but sometimes turbulent. They are best known for their destruction, yet their equally real but vital role of benefactor of ten passes unnoticed.

"This booklet is intended primarily as a supplementary text for range management students at the college level and as an abbreviated reference for others interested in rangeland insects." 